\title{
Carbapenem stewardship with ertapenem and antimicrobial resistance-a scoping review
}

\author{
Tiago Zequinão[1], João Paulo Telles ${ }^{[1],[2], ~ J u l i a n o ~ G a s p a r e t t o ~}{ }^{[1]}$ and Felipe Francisco Tuon ${ }^{[1]}$
}

[1]. Pontifícia Universidade Católica do Paraná, Faculdade de Medicina, Laboratório de Doenças Infecciosas Emergentes, Curitiba, PR, Brasil.

[2]. A.C.Camargo Cancer Center, São Paulo, SP, Brasil.

\begin{abstract}
Consumption of carbapenem has increased due to extended-spectrum beta-lactamase-producing bacteria spreading. Ertapenem has been suggested as a not carbapenem-resistance inducer. We performed a scoping review of carbapenem-sparing stewardship with ertapenem and its impact on the antibiotic resistance of Gram-negative bacilli. We searched PubMed for studies that used ertapenem as a strategy to reduce resistance to carbapenems and included epidemiologic studies with this strategy to evaluate susceptibility patterns to cephalosporins, quinolones, and carbapenems in Gram-negative-bacilli. The search period included only studies in English, up to February 2018. From 1294 articles, 12 studies were included, mostly from the Americas. Enterobacteriaceae resistance to quinolones and cephalosporins was evaluated in 6 studies and carbapenem resistance in 4 studies. Group 2 carbapenem (imipenem/meropenem/doripenem) resistance on A. baumannii was evaluated in 6 studies. All studies evaluated P. aeruginosa resistance to Group 2 carbapenem. Resistance profiles of Enterobacteriaceae and P. aeruginosa to Group 2 carbapenems were not associated with ertapenem consumption. The resistance rate of $A$. baumannii to Group 2 carbapenems after ertapenem introduction was not clear due to a lack of studies without bias. In summary, ertapenem as a strategy to spare use of Group 2 carbapenems may be an option to stewardship programs without increasing resistance of Enterobacteriaceae and P. aeruginosa. More studies are needed to evaluate the influence of ertapenem on A. baumannii.
\end{abstract}

Keywords: Antimicrobial stewardship. Ertapenem. Carbapenem-sparing.

\section{INTRODUCTION}

Ertapenem is a carbapenem with weak activity against Pseudomonas spp. and Acinetobacter spp. ${ }^{1}$. In randomized controlled trials, ertapenem has been used for severe communityacquired infections and is licensed for intra-abdominal infections, community-acquired pneumonia, skin and soft tissue infections, and complicated urinary infections ${ }^{2}$. The importance of ertapenem increased after dissemination of extended-spectrum $\beta$-lactamases (ESBLs), which are now disseminating outside hospitals ${ }^{3}$.

Carbapenems from Group 1 (i.e., ertapenem) and Group 2 (i.e., meropenem) may select for resistant $P$. aeruginosa in vitro ${ }^{4}$. Nevertheless, the selection of carbapenem-resistant $P$. aeruginosa has been shown to be unlikely under physiological ertapenem concentrations. Considering the antimicrobial selective pressure,

\footnotetext{
Corresponding author: João Paulo Telles

e-mail:.jpmarochi@hotmail.com

(iD) https://orcid.org/0000-0003-4078-2046

Received 2 August 2020

Accepted 24 August 2020
}

carbapenem-sparing stewardship strategies have increased in recent years ${ }^{5}$. However, some authors advocate ertapenem as a strategy to reduce resistance to meropenem and imipenem.

Considering the increasing importance of strategies to reduce antibiotic resistance, in this scoping review, we evaluated the effectiveness of an ertapenem-based stewardship strategy in reducing antibiotic resistance in Gram-negative bacilli (GNB).

\section{METHODS}

\section{Search strategy}

Using PubMed, we searched for studies published in English that used ertapenem as a strategy to reduce resistance to any antibiotic. The search included studies from inception to February 2018. The keyword used was "ertapenem" in title and abstract in the advanced search option.

\section{Data extraction and quality evaluation}

Two reviewers (JT and FT) independently screened all studies based on either title or abstract for eligibility. Discrepancies were resolved through discussion. Reviewers then independently 
extracted the relevant data from all the publications included in the review. A third reviewer evaluated the discrepancies. The methodological quality of each publication was not analyzed using classical scores for randomized clinical trials, but basic elements for an objective evaluation were included in a table for critical analysis.

\section{Inclusion and exclusion criteria}

The inclusion criteria were as follows: $i$ ) epidemiological studies that compared different periods of ertapenem consumption (i.e., pre vs. post introduction) and $i$ ) Evaluation of Group 2 carbapenem susceptibility pattern on Gram-negative bacilli. The exclusion criteria were: $i$ ) articles classified as case reports or individual data and/or $i$ ) undescribed data of ertapenem consumption or susceptibility patterns.

\section{Definitions and Gram-negative bacilli}

The ertapenem consumption model was defined as DDD per patientday (i.e., DDD/100PD, DDD/1000PD). Susceptibility and resistance evaluation were described in a published original article. Susceptibility patterns were considered according to the Clinical and Laboratory Standards Institute (CLSI) or European Committee on Antimicrobial Susceptibility Testing (EUCAST). The analyzed resistances according to each GNB were: $i$ ) quinolone in $E$. coli and $K$. pneumoniae, ii) third-generation cephalosporin in E. coli and $K$. pneumoniae, and iii) carbapenems in E. coli, K. pneumoniae, A. baumannii, and P. aeruginosa.

\section{RESULTS}

\section{Selected articles}

The search criteria initially identified 1294 articles. After title and abstract reviews, only 12 articles fulfilled the inclusion criteria (Figure 1). The first study was published in 2008 and the last in 2015. The period of analysis varied between 2000 and 2011.

Of the articles, 7 were from America ${ }^{6-12}, 4$ from Asia $^{13-16}$, and 1 from Europe ${ }^{17}$. A timeline of the ertapenem-based stewardship program of each study is presented in Figure 2.

Enterobacteriaceae susceptibility patterns to quinolones were evaluated in 5 studies ${ }^{6,11,13-15}, 6$ studies evaluated it susceptibility to cephalosporins $^{6,12-16}$, and 4 studies to Group 2 carbapenems ${ }^{6,9,12,13}$. Non-fermenting Gram-negative bacilli susceptibility patterns to Group 2 carbapenems were evaluated in 6 studies of A. baumannit ${ }^{6,9,13,15-17}$ and all studies evaluated Group 2 carbapenems susceptibility in $P$. aeruginosa.

\section{Carbapenem consumption}

Carbapenem consumption (Groups 1 and 2) was evaluated using different methods. Three studies used the slope curve and nine used comparative periods (before and after consumption). Thus, there was heterogeneity in the metrics used among authors, which complicates the establishment of a median or average value. Only 2 studies demonstrated the substitution tendency of Group 2 carbapenems to ertapenem after its introduction ${ }^{10,11}$.

\section{E. coli susceptibility}

Three studies analyzed ertapenem consumption and E. coli carbapenem resistance rate $\mathrm{e}^{6,12,13}$ and one did not specify resistance

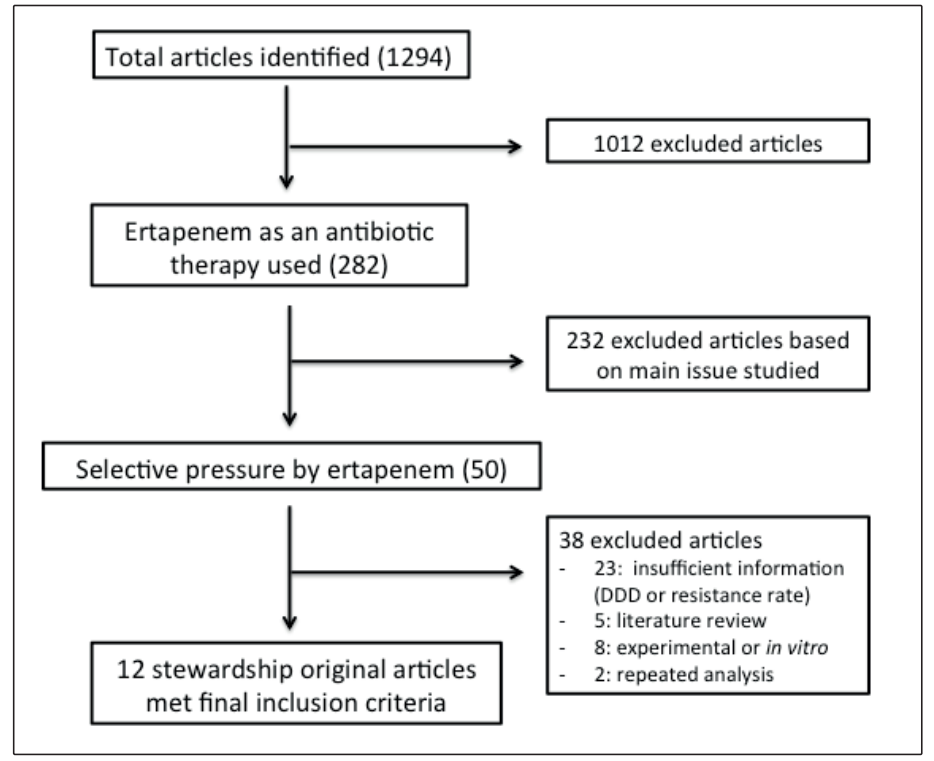

FIGURE 1: Flowchart for ertapenem studies and antibiotic stewardship.

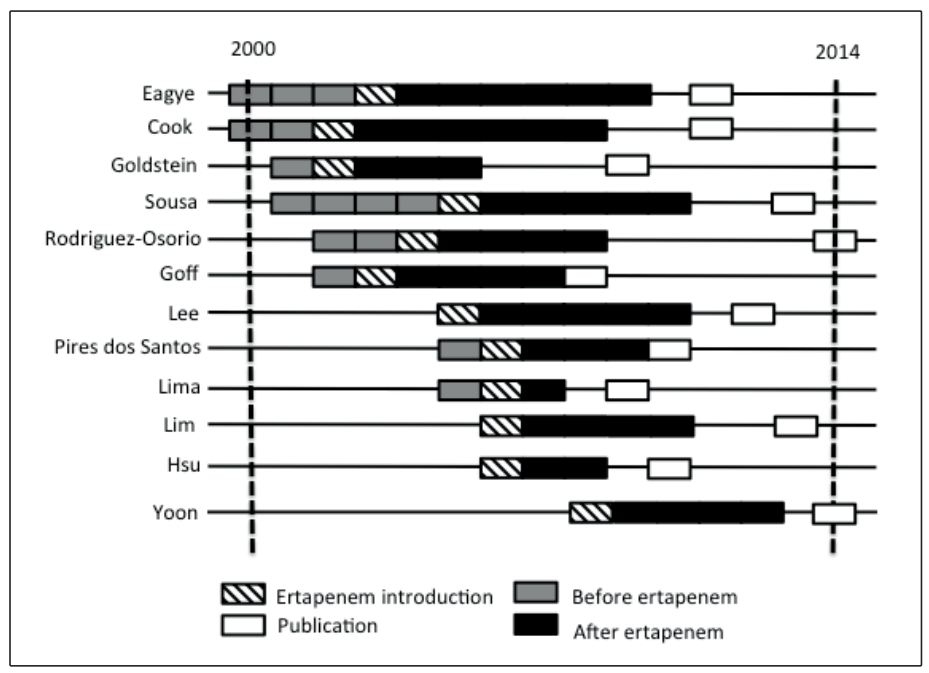

FIGURE 2: Historical profile of the publications regarding antibiotic stewardship with ertapenem.

among Enterobacteriaceae isolates ${ }^{9}$ (Tables 1 and Supplementary Data - Table 2). Increased ertapenem consumption did not increase $E$. coli resistance to carbapenems. Quinolones were analyzed by 4 studies and third-generation cephalosporins by 6 , and presented bias on results $^{6,11-16}$ (Supplementary Data - Table 2). Only 1 publication found a significant increase in quinolone resistance, although higher ciprofloxacin consumption was observed as well ${ }^{15}$. An increased resistance rate to third-generation cephalosporin was observed in 4 studies, but ceftriaxone, ceftazidime, and beta-lactamase inhibitor consumption rates were also higher in 3 studies $^{6,13,15,16}$.

\section{K. pneumoniae susceptibility}

Three studies analyzed ertapenem consumption and K. pneumoniae carbapenem resistance rate ${ }^{6,12,13}$, and one did not specify resistance among Enterobacteriaceae isolates ${ }^{9}$ (Table 1). Increased consumption of ertapenem changed the susceptibility 
TABLE 1: Characteristics of studies included in the review and antibiotics consumption.

\begin{tabular}{|c|c|c|c|c|c|c|c|}
\hline $\begin{array}{l}\text { Author } \\
\text { (year) }\end{array}$ & $\begin{array}{l}\text { Study } \\
\text { design }\end{array}$ & $\begin{array}{l}\text { Hospital } \\
\text { settings }\end{array}$ & $\begin{array}{l}\text { Antibiotic consumption } \\
\text { measure and metric }\end{array}$ & $\begin{array}{l}\text { Ertapenem } \\
\text { consumption }\end{array}$ & $\begin{array}{c}\text { Group } 2 \\
\text { carbapenem } \\
\text { consumption }\end{array}$ & $\begin{array}{l}\text { Extended-spectrum } \\
\text { cephalosporins } \\
\text { consumption }\end{array}$ & $\begin{array}{c}\text { Fluoroquinolones } \\
\text { consumption }\end{array}$ \\
\hline $\begin{array}{l}\text { Cook et al. } \\
(2011)^{9}\end{array}$ & $\begin{array}{l}\text { Retrospective } \\
\text { time-series }\end{array}$ & $\begin{array}{c}861 \text { beds } \\
\text { medical/surgical }\end{array}$ & $\begin{array}{c}\text { graphic plots DDD/1000 } \\
\text { PD ertapenem } \\
\text { introduction quarter vs last } \\
\text { quarter }\end{array}$ & $\begin{array}{l}0.0 \text { vs } 18.0 \\
(p \text { value NP) }\end{array}$ & $\begin{array}{c}10.0 \text { vs } 15.00 \\
(p \text { value NP) }\end{array}$ & $\begin{array}{l}20.0 \text { vs } 38.0 \\
(p \text { value NP) }\end{array}$ & $\begin{array}{l}90.0 \text { vs } 10.0 \\
(p \text { value NP) }\end{array}$ \\
\hline $\begin{array}{l}\text { Eagye and } \\
\text { Nicolau } \\
(2011)^{8}\end{array}$ & $\begin{array}{l}\text { Retrospective } \\
\text { time-series }\end{array}$ & 25 hospitals & $\begin{array}{c}\text { introduction year vs last } \\
\text { year (ertapenem) } \\
\text { first year vs last year } \\
\text { (others) } \\
\text { annually DDD/1000 PD }\end{array}$ & $\begin{array}{c}7.27 \text { vs } 15.93 \\
(p \text { value } N P)\end{array}$ & $\begin{array}{c}10.39 \text { vs } 15.27 \\
(p \text { value } N P)\end{array}$ & NP & $\begin{array}{c}303.84 \text { vs } 423.82 \\
\quad(p \text { value NP) }\end{array}$ \\
\hline $\begin{array}{l}\text { Goff and } \\
\text { Mangino } \\
(2008)^{12}\end{array}$ & $\begin{array}{l}\text { Retrospective } \\
\text { time-seriess }\end{array}$ & $\begin{array}{c}770 \text { beds } \\
\text { medical/surgical }\end{array}$ & $\begin{array}{l}\text { first year vs last year } \\
\text { annual DDD/1000 PD }\end{array}$ & $\begin{array}{c}3.4 \text { vs } 8.9 \\
(R R=2.61 \\
p<0.001)\end{array}$ & $\begin{array}{c}\text { IPM } 21.5 \text { vs } 31.1 \\
(R R=1.45, p<0.001)\end{array}$ & CPM 18.8 vs 63.0 & NP \\
\hline $\begin{array}{l}\text { Goldstein } \\
\text { et al. } \\
(2009)^{11}\end{array}$ & $\begin{array}{l}\text { Retrospective } \\
\text { interrupted } \\
\text { time-series }\end{array}$ & 344 beds & $\begin{array}{l}\text { introduction period } \\
\text { median vs last period } \\
\text { median (ertapenem) } \\
\text { post intervention slope } \\
\text { (others) } \\
\text { monthly DDD/1000 PD }\end{array}$ & $\begin{array}{l}8.0 \text { vs } 44.0 \\
(p \text { value NP) }\end{array}$ & $\begin{array}{l}\text { IPM decreased } \\
1.28(p=0.002)\end{array}$ & $\begin{array}{c}\text { CPM stable } \\
\text { (coefficients NP) }\end{array}$ & $\begin{array}{c}\text { LVX stable } \\
\text { (coefficients NP) }\end{array}$ \\
\hline $\begin{array}{l}\text { Hsu et al. } \\
(2010)^{15}\end{array}$ & $\begin{array}{l}\text { Retrospective } \\
\text { time-series }\end{array}$ & $\begin{array}{l}4 \text { hospitals } \\
\text { totalizing } \\
4000 \text { beds }\end{array}$ & $\begin{array}{c}\text { slope } 3 \text { months DDD/1000 } \\
\text { PD throughout the entire } \\
\text { period }\end{array}$ & $\begin{array}{c}\text { increased } \\
0.079 \\
(p<0.05)\end{array}$ & $\begin{array}{c}\text { MEM increased } \\
0.057 \\
(p=0.03) \\
\text { IPM decreased } 0.057 \\
(p<0.05)\end{array}$ & $\begin{array}{l}{ }^{*} \text { stable } \\
(p=0.23)\end{array}$ & $\begin{array}{c}{ }^{* *} \text { increased } \\
1.677(p<0.05)\end{array}$ \\
\hline $\begin{array}{l}\text { Lee et al. } \\
(2013)^{13}\end{array}$ & $\begin{array}{l}\text { Retrospective } \\
\text { time-series }\end{array}$ & 1130 beds & $\begin{array}{c}\text { slope annually DDD/1000 } \\
\text { PD } \\
\text { throughout the entire } \\
\text { period }\end{array}$ & $\begin{array}{c}\text { increased } \\
4.818 \\
(p<0.001)\end{array}$ & $\begin{array}{c}\text { MEM increased } \\
1.557 \\
(p<0.001), \\
\text { IPM increased } 0.774 \\
(p<0.001)\end{array}$ & $\begin{array}{c}\text { CRO }(p=0.2079), \\
\text { CAZ increased } 0.862 \\
(p<0.001), \\
\text { CPM }(p=0.544), \\
\text { Cefpirome increased } \\
0.916(p=0.0426)\end{array}$ & $\begin{array}{c}\text { CIP increased } 0.50 \\
(p<0.001), \\
\text { LVX increased } 3.84 \\
(p<0.001), \\
\text { MXF increased } \\
2.674(p<0.001)\end{array}$ \\
\hline $\begin{array}{l}\text { Lim et al. } \\
(2013)^{14}\end{array}$ & $\begin{array}{l}\text { Retrospective } \\
\text { time-series }\end{array}$ & NP & $\begin{array}{l}\text { first month vs last month } \\
\text { DDD/100 PD }\end{array}$ & $\begin{array}{c}0.45 \text { vs } 1.2 \\
(p \text { value NP) }\end{array}$ & $\begin{array}{c}\text { MEM } 2.0 \text { vs } 3.2 \\
\text { ( } p \text { value NP), IPM } 1.8 \\
\text { vs } 0.7 \\
(p \text { value } N P)\end{array}$ & $\begin{array}{l}\text { CRO } 5.61 \text { vs } 12.5 \text { (p } \\
\text { value NP), CPM } 5.4 \\
\text { vs } 4.7(p \text { value NP) }\end{array}$ & $\begin{array}{l}\text { CIP } 1.17 \text { vs } 1.3 \\
(p \text { value NP) }\end{array}$ \\
\hline $\begin{array}{l}\text { Lima et al. } \\
(2009)^{10}\end{array}$ & $\begin{array}{l}\text { Retrospective } \\
\text { time-series }\end{array}$ & $\begin{array}{c}200 \text { beds } \\
\text { trauma/orthopedic }\end{array}$ & $\begin{array}{c}\text { pre period vs post period } \\
\text { DDD/1000 PD }\end{array}$ & 0.0 vs 42.6 & $\begin{array}{l}\text { IPM } 46.3 \text { vs } 16.1 \\
(p<0.001)\end{array}$ & NP & NP \\
\hline $\begin{array}{l}\text { Pires dos } \\
\text { Santos et al. } \\
(2011)^{7}\end{array}$ & $\begin{array}{l}\text { Retrospective } \\
\text { interrupted } \\
\text { time-series }\end{array}$ & $\begin{array}{c}749 \text { beds } \\
\text { medical/surgical }\end{array}$ & $\begin{array}{l}\text { pre period vs ertapenem } \\
\text { period } \\
\text { monthly DDD/100 PD }\end{array}$ & $\begin{array}{l}0.05 \text { median } \\
\text { throughout } \\
\text { ertapenem } \\
\text { period }\end{array}$ & $\begin{array}{c}2.6 \text { vs } 2.2 \\
(p=0.08)\end{array}$ & $\begin{array}{l}1.1 \text { vs } 0.8 \\
(p<0.05)\end{array}$ & $\begin{array}{c}10.1 \text { vs } 3.6 \\
(p<0.05)\end{array}$ \\
\hline $\begin{array}{l}\text { Rodriguez- } \\
\text { Osorio et al. } \\
(2015)^{6}\end{array}$ & $\begin{array}{l}\text { Retrospective } \\
\text { time-series }\end{array}$ & $\begin{array}{c}280 \text { beds medical/ } \\
\text { surgical }\end{array}$ & $\begin{array}{c}\text { slope } 4 \text { months DDD/1000 } \\
\text { PD throughout the entire } \\
\text { period }\end{array}$ & $\begin{array}{l}\text { increased } 15.5 \\
\qquad(p<0.001)\end{array}$ & $\begin{array}{c}\dagger \text { increased } \\
26.6(p<0.001)\end{array}$ & $\begin{array}{c}{ }^{*} \text { Decreased } 32.2 \\
(p=0.007)\end{array}$ & $\begin{array}{c}\text { †† decreased } 38.6 \\
(p<0.001)\end{array}$ \\
\hline $\begin{array}{l}\text { Sousa et al. } \\
\qquad(2013)^{17}\end{array}$ & $\begin{array}{l}\text { Retrospective } \\
\text { interrupted } \\
\text { time-series }\end{array}$ & $\begin{array}{c}1445 \text { beds } \\
\text { medical/surgical }\end{array}$ & $\begin{array}{l}\text { introduction year vs last } \\
\text { year (ertapenem) } \\
\text { slope change (others) } \\
\text { monthly DDD/100 PD }\end{array}$ & $\begin{array}{c}0.09 \text { vs } 2.02 \\
(p<0.001)\end{array}$ & stable $(p=0.56)$ & $\begin{array}{c}\text { CRO } \\
\text { stable }(0.082)\end{array}$ & $\begin{array}{c}\text { stable } \\
(p=0.533)\end{array}$ \\
\hline $\begin{array}{l}\text { Yoon et al. } \\
(2014)^{16}\end{array}$ & $\begin{array}{l}\text { Before-and- } \\
\text { after }\end{array}$ & $\begin{array}{c}950 \text { beds } \\
\text { medical/surgical }\end{array}$ & $\begin{array}{l}\text { first period vs last period } \\
\text { monthly DDD/1000 PD }\end{array}$ & $\begin{array}{l}2.7 \text { vs } 7.2 \\
(p<0.001)\end{array}$ & $\begin{array}{c}20.7 \text { vs } 15.5 \\
(p=0.028)\end{array}$ & $\begin{array}{c}102.2 \text { vs } 96.7 \\
(p=0.311)\end{array}$ & $\begin{array}{c}57.7 \text { vs } 67.1 \\
(p=0.102)\end{array}$ \\
\hline
\end{tabular}

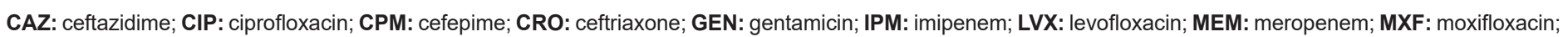

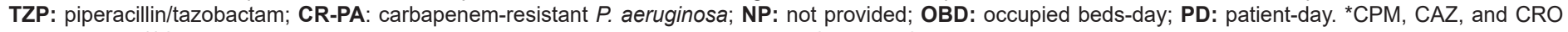
consumption. ${ }^{* *} \mathrm{CIP}, \mathrm{LVX}$, and MXF consumption. † MEM and IPM consumption. †† CIP and ofloxacin consumption.

patterns of carbapenems in some studies. One study showed a slight improvement in carbapenem susceptibility ${ }^{13}$. Another study found a higher incidence of resistance to Group 2 carbapenems on univariate analysis; however, higher consumption of meropenem/imipenem was observed ${ }^{6}$. Quinolones and third-generation cephalosporin susceptibility were analyzed in 4 and 6 studies respectively, ${ }^{6,12-16}$ (Supplementary Data - Table 2). Increased third-generation cephalosporin resistance was observed in 4 studies $^{6,12,13,16}$.

\section{A. baumannii susceptibility}

Six studies analyzed ertapenem consumption and A. baumannii carbapenem resistance rates ${ }^{6,913,15-17}$ (Tables 1 and Supplementary Data - Table 2). Increased consumption was associated with a decrease in susceptibility patterns in 2 studies $^{13,15}$. Nevertheless, both of them increased meropenem and/or imipenem consumption and 1 increased resistance only on univariate analysis ${ }^{13,15}$. 


\section{P. aeruginosa susceptibility}

Twelve studies analyzed ertapenem consumption and P. aeruginosa carbapenem resistance rates (Tables 1 and Supplementary Data Table 2 $)^{6-17}$. Results were variable. Three studies demonstrated significant susceptibility pattern improvement ${ }^{9,11,17}$. Six did not observe significant changes in resistance patterns ${ }^{7,8,10,12,15,16}$. Three studies demonstrated a higher carbapenem resistance rate after ertapenem introduction ${ }^{6,13,14}$. However, 2 studies increased Group 2 carbapenem consumption as well ${ }^{6,14}$, and one of them did not present significant statistical results on multivariate analysis ${ }^{6}$.

\section{DISCUSSION}

We conducted a scoping review to better understand Gramnegative bacilli antibiotic resistance and ertapenem consumption. Twelve studies evaluated ertapenem consumption as an intervention to change Group 2 carbapenem resistance. After this strategy, the Group 2 carbapenem was reduced in 3 studies. Carbapenem resistance in Enterobacteriaceae did not increase after ertapenem consumption. However, non-fermenting Gram-negative bacilli demonstrated changes in susceptibility patterns. Carbapenemresistant in A. baumannii increased in 2 of 6 studies, while 4 observed no difference. P. aeruginosa improved carbapenem susceptibility in 3 of the 12 studies, while 7 observed no differences and 2 increased carbapenem resistance.

The hypothesis that ertapenem has the potential to select $P$. aeruginosa and A. baumannii resistant to Group 2 carbapenems is due to its limited action on non-fermenting Gram-negative bacilli (NF-GNB). Previous reviews did not observe higher rates of carbapenem resistance in NF-GNB despite an increase in ertapenem consumption $^{18,19}$.

The carbapenem resistance rate in E. coli did not increase after ertapenem consumption. Studies have observed changes in E. coli susceptibility only to cephalosporins and quinolones. Hsu et al. (2010) observed that increased resistance to ceftriaxone and ciprofloxacin correlated with increasing consumption ${ }^{15}$. Lee et al. (2010) found increased susceptibility to ceftazidime and levofloxacin in addition to increasing its consumption ${ }^{13}$.

K. pneumoniae carbapenem resistance rate did not increase overall and it was positively affected by routine utilization of ertapenem in one study. Lee et al. (2010) observed an improvement in susceptibility to carbapenems, ceftazidime, and levofloxacin after ertapenem introduction ${ }^{13}$. Changes in the resistance rate of $K$. pneumoniae to cephalosporin and quinolones were observed. Hsu et al. (2010) demonstrated lower resistance to ceftriaxone and ciprofloxacin but this was not correlated with antibiotic consumption ${ }^{15}$. Goff and Mangino (2008) observed higher resistance to cephalosporins in the latter period and inferred it was due to multiple hospitalizations ${ }^{12}$. Overall, Enterobacteriaceae carbapenem resistance was not affected by ertapenem consumption. These results are in accordance with stable CRE colonization rates after patients using ertapenem as surgical prophylaxis ${ }^{20}$.

A. baumannii demonstrated predominantly no difference in the results and worst susceptibility patterns in 2 studies $^{13,15}$. However, there was a significant increase in consumption in Group 2 carbapenems and other broad-spectrum antibiotics.
Yoon et al converged with these results when they concluded that carbapenem resistance rate is correlated with Group 2 carbapenem consumption ${ }^{16}$.

Carbapenem-resistant $P$. aeruginosa was not increased by ertapenem use in the majority of studies. Increased resistance rates were demonstrated in a study with higher Group 2 carbapenem consumption ${ }^{13}$. Nevertheless, Lim et al. (2013) observed a negative impact on carbapenem susceptibility even with no difference in Group 2 carbapenem consumption in both periods ${ }^{14}$. Similar to $A$. baumannii, other studies found that $P$. aeruginosa resistance was affected by Group 2 carbapenem consumption but not by ertapenem ${ }^{21,22}$. These studies converged with two positive results in the present review ${ }^{11,17}$, in which lower resistance was correlated with less usage of imipenem. Only one study directly associated ertapenem consumption with better carbapenem susceptibility 9

The present study has several limitations. Methods heterogeneity may make certain conclusions difficult when studies were not comparable between each other. Other factors may have influenced the carbapenem resistance rate of Group 2, such as higher meropenem/imipenem consumption, without multivariate analysis evaluation. However, this article presents a relevant issue in infectious disease practice and may help stewardship programs to adequately choose carbapenem therapeutic regimens without affecting the bacterial resistance rate.

\section{CONCLUSION}

The majority of studies did not demonstrate a rising Group 2 carbapenem resistance rate in Enterobacteriaceae and $P$. aeruginosa after ertapenem introduction. The rate of resistance to Group 2 carbapenems on A. baumannii is not clear. However, studies did demonstrate that worsening carbapenem resistance was associated with Group 2. If a carbapenem group is needed in an antimicrobial stewardship program, ertapenem may be an option to spare Group 2 carbapenem usage without increasing resistance in Enterobacteriaceae and P. aeruginosa.

\section{AUTHORS' CONTRIBUTION}

TZ: Wrote manuscripts, articles review and selection, analysis and interpretation of data. JPT: Conception and design of the study, articles reviewer and selection, manuscript review. JG: Final manuscript review. FFT: Conception and design of the study, articles reviewer and selection, final approval of the version to be submitted.

\section{CONFLICTS OF INTEREST}

Felipe Tuon conducts research for CNPQ.

\section{FINANCIAL SUPPORT}

The authors have no funding to report.

\section{REFERENCES}

1. Livermore DM, Sefton AM, Scott GM. Properties and potential of ertapenem. J Antimicrob Chemother. 2003;52(3):331-44.

2. Congeni BL. Ertapenem. Expert Opin Pharmacother. 2010;11(4):669-72.

3. Rocha JL, Tuon FF, Johnson JR. Sex, drugs, bugs, and age: rational selection of empirical therapy for outpatient urinary tract infection in an era of extensive antimicrobial resistance. Braz J Infect Dis. 2012;16(2):115-21. 
4. Livermore DM, Mushtaq S, Warner M. Selectivity of ertapenem for Pseudomonas aeruginosa mutants cross-resistant to other carbapenems. J Antimicrob Chemother. 2005; 55(3):306-11.

5. Abdallah M, Badawi M, Amirah MF, Rasheed A, Mady AF, Alodat $\mathrm{M}$, Alharthy A. Impact of carbapenem restriction on the antimicrobial susceptibility pattern of Pseudomonas aeruginosa isolates in the ICU. J Antimicrob Chemother. 2017;72(11):3187-90.

6. Rodriguez-Osorio CA, Sanchez-Martinez CO, Araujo-Melendez J, Criollo E, Macias-Hernandez AE, Ponce-de-Leon A, Ponce-de-Leon S, Sifuentes-Osornio J. Impact of ertapenem on antimicrobial resistance in a sentinel group of Gram-negative bacilli: a 6 year antimicrobial resistance surveillance study. J Antimicrob Chemother. 2015; 70(3):914-21.

7. Pires dos Santos R, Jacoby T, Pires Machado D, Lisboa T, Gastal SL, Nagel FM, Kuplich NM, Konkewicz L, Gorniak Lovatto C, Pires MR, Goldani LZ. Hand hygiene, and not ertapenem use, contributed to reduction of carbapenem-resistant Pseudomonas aeruginosa rates. Infect Control Hosp Epidemiol. 2011;32(6):584-90.

8. Eagye KJ, Nicolau DP. Change in antipseudomonal carbapenem susceptibility in 25 hospitals across 9 years is not associated with the use of ertapenem. J Antimicrob Chemother. 2011;66(6):1392-95.

9. Cook PP, Gooch M, Rizzo S. Reduction in fluoroquinolone use following introduction of ertapenem into a hospital formulary is associated with improvement in susceptibility of Pseudomonas aeruginosa to group 2 carbapenems: a 10-year study. Antimicrob Agents Chemother. 2011;55(12):5597-601.

10. Lima AL, Oliveira PR, Paula AP, Dal-Paz K, Rossi F, Zumiotti AV. The impact of ertapenem use on the susceptibility of Pseudomonas aeruginosa to imipenem: a hospital case study. Infect Control Hosp Epidemiol. 2009;30(5):487-90.

11. Goldstein EJ, Citron DM, Peraino V, Elgourt T, Meibohm AR, Lu $\mathrm{S}$. Introduction of ertapenem into a hospital formulary: effect on antimicrobial usage and improved in vitro susceptibility of Pseudomonas aeruginosa. Antimicrob Agents Chemother. 2009;53(12):5122-6.

12. Goff DA, Mangino JE. Ertapenem: no effect on aerobic gram-negative susceptibilities to imipenem. J Infect. 2008;57(2):123-7.

13. Lee CM, Lai CC, Wang YY, Lee MC, Hsueh PR. Impact of susceptibility profiles of Gram-negative bacteria before and after the introduction of ertapenem at a medical center in northern Taiwan from 2004 to 2010. Diagn Microbiol Infect Dis. 2013;75(1):94-100.
14. Lim CL, Lee W, Lee AL, Liew LT, Nah SC, Wan CN, Chlebicki MP, Kwa AL. Evaluation of Ertapenem use with impact assessment on extended-spectrum beta-lactamases (ESBL) production and gramnegative resistance in Singapore General Hospital (SGH). BMC Infect Dis. 2013;13:523.

15. Hsu LY, Tan TY, Tam VH, Kwa A, Fisher DA, Koh TH, S. Network for Antimicrobial Resistance, Surveillance and correlation of antibiotic prescription and resistance of Gram-negative bacteria in Singaporean hospitals. Antimicrob Agents Chemother. 2010;54(3):1173-8.

16. Yoon YK, Yang KS, Lee SE, Kim HJ, Sohn JW, Kim MJ. Effects of Group 1 versus Group 2 carbapenems on the susceptibility of Acinetobacter baumannii to carbapenems: a before and after intervention study of carbapenem-use stewardship. PLoS One. 2014; 9(6):e99101.

17. Sousa D, Castelo-Corral L, Gutierrez-Urbon JM, Molina F, LopezCalvino B, Bou G, Llinares P. Impact of ertapenem use on Pseudomonas aeruginosa and Acinetobacter baumannii imipenem susceptibility rates: collateral damage or positive effect on hospital ecology? J Antimicrob Chemother. 2013;68(8):1917-25.

18. Nicolau DP, Carmeli Y, Crank CW, Goff DA, Graber CJ, Lima AL, Goldstein EJ. Carbapenem stewardship: does ertapenem affect Pseudomonas susceptibility to other carbapenems? A review of the evidence. Int J Antimicrob Agents. 2012;39(1): 11-15.

19. Falagas ME, Tansarli GS, Kapaskelis A, Vardakas KZ. Ertapenem use and antimicrobial resistance to group 2 carbapenems in Gramnegative infections: a systematic review. Expert Rev Anti Infect Ther. 2013;11(1):69-78.

20. Bloomfield MG, Page MJ, McLachlan AG, Studd RC, Blackmore TK. Routine Ertapenem Prophylaxis for Transrectal Ultrasound Guided Prostate Biopsy does Not Select for Carbapenem Resistant Organisms: A Prospective Cohort Study. J Urol. 2017;198(2):362-68.

21. Carmeli Y, Lidji SK, Shabtai E, Navon-Venezia S, Schwaber MJ. The effects of group 1 versus group 2 carbapenems on imipenem-resistant Pseudomonas aeruginosa: an ecological study. Diagn Microbiol Infect Dis. 2011;70(3):367-72.

22. McDougall DA, Morton AP, Playford EG. Association of ertapenem and antipseudomonal carbapenem usage and carbapenem resistance in Pseudomonas aeruginosa among 12 hospitals in Queensland, Australia. J Antimicrob Chemother. 2013;68(2):457-60. 
SUPPLEMENTARY DATA - TABLE 2: Microorganism resistance to antibiotics and conclusions.

\begin{tabular}{|c|c|c|c|c|c|c|c|}
\hline & $\begin{array}{l}\text { Microorganisms } \\
\text { analysis } \\
\text { measure and } \\
\text { metric }\end{array}$ & $\begin{array}{l}\text { Impact on NF- } \\
\text { GBN } \\
\text { resistance } \\
\text { to Group } 2 \\
\text { carbapenems }\end{array}$ & $\begin{array}{l}\text { Impact on } \\
\text { Enterobacteriaceae } \\
\text { resistance to group } \\
2 \text { carbapenems }\end{array}$ & $\begin{array}{l}\text { Impact on } \\
\text { Enterobacteriaceae } \\
\text { resistance to } \\
\text { cephalosporins/quinolones }\end{array}$ & $\begin{array}{l}\text { Correlation } \\
\text { between ertapenem } \\
\text { consumption and GNB } \\
\text { resistance to } \\
\text { carbapenems }\end{array}$ & Comments & Conclusion \\
\hline $\begin{array}{l}\text { Cook et al. } \\
(2011)^{9}\end{array}$ & $\begin{array}{l}\text { graphic plots } \\
\% \text { of resistants }\end{array}$ & $\begin{array}{l}-P . \text { aeruginosa } \\
24 \% \text { vs } 16 \% \\
\text { ( } p \text { value NP) } \\
\text { - } A \text {. baumannii } \\
\text { no difference } \\
\text { ( } p \text { value NP) }\end{array}$ & $\begin{array}{l}\text { no difference } \\
\text { ( } p \text { value NP) }\end{array}$ & NP & $\begin{array}{l}-P . \text { aeruginosa } \% \text { of } \\
\text { resistants correlation } \\
\text { coefficient }=-0.45815 \text {, } \\
p=0.003 \\
\text { - A. baumannii NP }\end{array}$ & $\begin{array}{l}\text { There was a } \\
\text { correlation of } \\
\text { ciprofloxacin use } \\
\text { with percentage and } \\
\text { rate of carbapenems } \\
\text { resistant } P \text {. } \\
\text { aeruginosa }\end{array}$ & $\begin{array}{l}\text { P. aeruginosa: } \\
\text { decreased resistance to } \\
\text { carbapenems } \\
\text { A. baumannii: no } \\
\text { difference } \\
\text { E. coli: no difference } \\
\text { K. pneumoniae: no } \\
\text { difference }\end{array}$ \\
\hline $\begin{array}{l}\text { Eagye and } \\
\text { Nicolau } \\
(2011)^{8}\end{array}$ & $\begin{array}{l}\text { first year vs last } \\
\text { year } \\
\% \text { of } \\
\text { susceptible }\end{array}$ & $\begin{array}{l}\text { - } P . \text { aeruginosa } \\
85.4 \% \text { vs } \\
81.0 \%(p=0.99) \\
\text { - A. baumannii } \\
\text { NP }\end{array}$ & NP & NP & NP & $\begin{array}{l}P . \text { aeruginosa } \\
\text { susceptibility } \\
\text { was not associated } \\
\text { with ertapenem use } \\
\text { neither other } \\
\text { antibiotic classes } \\
\text { across the study }\end{array}$ & $\begin{array}{l}\text { P. aeruginosa: no } \\
\text { difference } \\
\text { A. baumannii: NP } \\
\text { E. coli: NP } \\
\text { K. pneumoniae: NP }\end{array}$ \\
\hline $\begin{array}{l}\text { Goff and } \\
\text { Mangino } \\
(2008)^{12}\end{array}$ & $\begin{array}{l}\text { first year vs last } \\
\text { year } \\
\text { annual \% of } \\
\text { susceptible }\end{array}$ & $\begin{array}{l}\text { - } P \text {. aeruginosa } \\
\text { to IPM } \\
71 \% \text { vs } 72 \% \\
(p=0.92) \\
\text { - A. baumannii } \\
\text { NP }\end{array}$ & $\begin{array}{l}\text { - E. coli to IPM: } \\
100 \% \text { vs } 100 \% \text { ( } p \\
\text { value NP) } \\
\text { - K. pneumoniae to } \\
\text { IPM: } \\
99 \% \text { vs } 99 \% \text { ( } p \\
\text { value NP) }\end{array}$ & $\begin{array}{l}\text { - E. coli ESBL: } 1,07 \% \text { vs } \\
2.00 \%(p=0.30) \\
-K . \text { pneumoniae ESBL: } \\
4 \% \text { vs } 18 \%(p<0.001)\end{array}$ & NP & $\begin{array}{l}\text { K. pneumoniae } \\
\text { ESBL isolates } \\
\text { increased was } \\
\text { justified due to } \\
\text { community or } \\
\text { transplanted } \\
\text { patients with } \\
\text { multiple } \\
\text { hospitalization on } \\
\text { later period }\end{array}$ & $\begin{array}{l}\text { P. aeuruginosa: no } \\
\text { difference } \\
\text { A. baumannii: NP } \\
\text { E. coli: no difference } \\
\text { K. pneumoniae: no } \\
\text { difference }\end{array}$ \\
\hline
\end{tabular}

\begin{tabular}{|c|c|c|c|c|c|}
\hline $\begin{array}{l}\text { Goldstein et } \\
\text { al. } \\
(2009)^{11}\end{array}$ & $\begin{array}{l}\text { slope } \\
\text { monthly \% of } \\
\text { susceptibles }\end{array}$ & $\begin{array}{l}\text { - } P \text {. aeruginosa } \\
\text { increased } 1.74 \\
(p<0.001) \\
-A . \text { baumannii } \\
\text { NP }\end{array}$ & NP & $\begin{array}{l}\text {-E. coli to LVX: } 90 \% \text { vs } \\
83 \% \text { ( } p \text { value NP) } \\
\text { - K. pneumoniae: NP }\end{array}$ & NP \\
\hline
\end{tabular}

The author $\quad P$. aeuruginosa: associated improved increased susceptibility susceptibities to IPM to Group 2 carbapenems

A. baumannii: NP

$\begin{array}{ll}\text { decreasing } & \text { E. coli: NP }\end{array}$

consumption $\quad$ K. pneumoniae: NP

A. baumannii

resistance to

carbapenems was

also correlated with

LEV and TZP

- $P$. aeruginosa $\quad-E$. coli to CRO, CIP: to IPM stable

slope $\quad(p=0.37)$

$\begin{array}{lll}\text { Hsu et } & 3 \text { months } & - \text { A. baumannii } \\ \text { al. }(2010)^{15} & \text { resistants/1000 } & \text { to IPM }\end{array}$

$\begin{array}{ll}\text { resistants/1000 } & \text { to IPM } \\ \mathrm{PD} & \text { increased on }\end{array}$

blood isolates

$(p=0.03)$ increased $0.032(p<0.05)$,

increased $0.031(p=0.02) \quad-P$. aeruginosa no

respectively.

K. pneumoniae to CRO baumannii positive

CIP: decreased $0.074 \quad$ correlation $(R 2=0.394)$ on

$(p<0.05)$, decreased 0.091 IPM resistance

$(p<0.05)$ respectively.

consumption. E. coli difference

resistance was also A. baumannii: Increased

correlated with

quinolones, TZP

and $\mathrm{CRO}$

resistance to Group 2

carbapenems on blood

consumption K E. coli: NP

pneumoniae

K. pneumonia: NP

resistance was no

correlated with

antibiotic

consumption.

There was a

significant negative

correlation of

ertapenem use and

MEM susceptibility

on GNB, but the

increased 8.903

and IPM: $\quad(p<0.001)$, stable $\quad$ coefficient $=-0.148$

0.798

$(p=0.2822)$, increased

$(p=0.0184)$ and

stable $(p=0.9209$

$\mathrm{p}=0.0330$ and correlation coefficient $=-0.355$,

K. pneumoniae to respectively.

$\mathrm{p}=0.1731$

$(2013)^{13} \quad$ annual \%

$(p=0.1786)$

-A. baumannii

to MEM and

MEM and IPM:

- K. pneumoniae to CAZ

increased 1.058

$(p<0.001)$ and

IPM:

CIP, LEV: increased

same with MEM use

and MEM

decreased

stable $(p=0.7877)$

$11.619(p<0.0027)$, stable

A. baumannii to MEM

and IMI: correlation

4.136

$\mathrm{p}=0.6844)$, increased

$20.722(p=0.0023)$.

$p<0.001$ and correlation

coefficient $=-1.077$, $\mathrm{p}<0.001$ susceptibility. Ther

was a significant

increase in $E$. col

susceptibility to

CAZ, but in other

hand, total E. coli
$P$. aeuruginosa

decreased susceptibility to Group 2 carbapenems

A baumannii: decreased

susceptibility to Group 2 carbapenems

E. coli: no difference

K. pneumoniae:

increased susceptibility

to Group 2 carbapenems 
decreased

5.195

$(p<0.001)$
ESBL-producing

increased.

$\begin{array}{lll} & & \\ & \text { first month vs } & -P . \text { aeruginosa } \\ \text { Lim et al. } & \text { last month } & 0.25 \text { vs } 0.35(\mathrm{p} \\ (2013)^{14} & \text { resistants/1000 } & \text { value NP) } \\ & \text { PD } & \text { A. baumannii } \\ & & \text { NP }\end{array}$

-E. coli to CRO, CIP: 1.6

vs 2.0 ( $p$ value NP), 3.2 vs $-P$. aeruginosa

3.7 ( $p$ value NP)

respectively.

- K. pneumoniae to $\mathrm{CRO}$,

CIP:2.4 vs 1.5 ( $p$ value

$\mathrm{NP}), 2.2$ vs 1.1 ( $\mathrm{p}$ value

NP) respectively. correlation coefficient $=$
$0.5648, \mathrm{R} 2=0.3190$

$\mathrm{p}=0.089$

-A. baumannii correlation coefficient $=-0.6485$,

$\mathrm{R} 2=0.0911, \mathrm{p}=0.397$

\begin{tabular}{|c|c|c|c|c|c|}
\hline $\begin{array}{l}\text { Lima et al. } \\
(2009)^{10}\end{array}$ & $\begin{array}{l}\text { pre period vs } \\
\text { post period } \\
\% \text { of resistants }\end{array}$ & $\begin{array}{l}\text { - } P \text {. aeruginosa } \\
20.0 \% \text { vs } 0.0 \% \\
(p>0.05) \\
- \text { A. baumannii } \\
\text { NP }\end{array}$ & NP & $\mathrm{NP}$ & NP \\
\hline
\end{tabular}

Pires dos

Santos et al. $(2011)^{7}$

$\begin{array}{lll} & & \\ \text { pre period vs } & -P \text {. } \\ \text { ertapenem } & \text { aeruginosa0.51 } \\ \text { period } & \text { vs } 0.43 & \text { NP } \\ \text { resistants/1000 } & \text { ( }=0.33) & - \text { A. baumannii } \\ \text { PD } & \text { NP }\end{array}$

\begin{tabular}{|c|c|c|}
\hline $\begin{array}{l}\text { Rodriguez- } \\
\text { Osorio et al. } \\
(2015)^{6}\end{array}$ & $\begin{array}{l}\text { slope } \\
4 \text { months } \\
\text { resistants } / 1000 \\
\text { isolates }\end{array}$ & $\begin{array}{l}\text { - } P \text {. aeruginosa } \\
\text { increased } 6.26 \\
(p<0.05) \\
\text { - A. baumannii } \\
\text { increased } \\
25.39 \\
(p<0.001)\end{array}$ \\
\hline $\begin{array}{l}\text { Sousa et al. } \\
(2013)^{17}\end{array}$ & $\begin{array}{l}\text { slope } \\
\text { monthly } \\
\text { resistants } / 1000 \\
\text { isolates on } \\
\text { ertapenem } \\
\text { period }\end{array}$ & $\begin{array}{l}-P . \\
\text { aeuruginosa to } \\
\text { IPM decreased } \\
0.005 \\
(p<0.001) \\
-A . \text { baumannii } \\
\text { to IPM stable } \\
(p=0.54)\end{array}$ \\
\hline $\begin{array}{l}\text { Yoon et al. } \\
(2014)^{16}\end{array}$ & $\begin{array}{l}\text { first period vs } \\
\text { last period } \\
\text { monthly } \\
\% \text { resistants }\end{array}$ & $\begin{array}{l}\text { - } P \text {. aeruginosa } \\
18.1 \% \text { vs } \\
19.4 \% \\
(p=0.648) \\
-A . \text { baumannii } \\
52.2 \% \text { vs } \\
69.9 \% \\
(p<0.001)\end{array}$ \\
\hline
\end{tabular}

-E. coli to CAZ, CRO, CIP: increased $6.92(p<0.001)$ increased 10.00 $(p<0.001)$, decreased 1.45 $(p>0.05)$ respectively. - $K$. pneumoniae to CAZ, NP - K. pneumoniae to CA $11.72(p<0.001), 17.52$ $(p<0.001), 2.29(p>0.05)$ respectively.

NP

E. coli ESBL $31.8 \%$ vs
K. pneumoniae $\mathrm{ESBL}$ ( $\mathrm{p}<0.001)$
$0.1 \%$ vs $41.7 \%$ ( $\mathrm{p}<0.001)$

\section{Correlation}

was not calculated

between ertapenem use and incidence of IPM resistant strains.

However, decreased IPM consumption was correlated to decreased IPM resistance

There was a correlation between Group 2 carbapenem consumption during a previous month and carbapenem resistant $A$. baumannii proportion on following month $(p=0.03)$
Conclusions were based on correlation of ertapenem use and incidence rate of resistant pathogens.

There was correlation between ertapenem increasing use and cefepime decreasing. MEM also increased its usage but was not statistically

measured.

Although a noticed difference in

resistance proportions, these numbers are about 20 vs 18 strains and no difference was noticed in the trend over time

Introduction of ertapenem was associated with a decrease in IPM and $P$. aeuruginosa: no MEM use. By multivariate analysis, only alcohol hand-gel was correlated with the decrease in CR$\mathrm{PA}$ in the last period In a

multiple linear regression analysis adjusted for length of stay, hospital acquired infections and other 10 antibiotic usag ertapenem was not associated with changes in resistances In a multiple regression analysis CIP, GEN, decreased resistance to IPM, outbreaks and Group 2 carbapenems other variables were $A$. baumannii: no associated with the difference incidence density of $\quad E$. coli: NP IPM resistance K. pneumoniae: NP strains.

\section{Despite an}

increased proportion

of carbapenem

resistant $A$.

A. baumannii: NP

E. coli: NP

K. pneumoniae: NP

$P$. aeuruginosa: no

difference

A. baumannii: no

difference

E. coli: no difference

K. pneumoniae: no difference

baumannii, there

was no correlation

with ertapenem

consumption on

previous month and

increased proportion

on following month $(p=0.941)$

CAZ: ceftazidime, CIP: ciprofloxacin, CPM: cefepime, CRO: ceftriaxone, GEN: gentamicin, IPM: imipenem, LVX: levofloxacin, MEM: meropenem,

MXF: moxifloxacin, TZP: piperacillin/tazobactam, CR-PA: carbapenem-resistant $P$. aeruginosa, NP: Not provided, OBD: occupied beds-day, PD: patient-day. 